\title{
Blang Chinese
}

National Cancer Institute

\section{Source}

National Cancer Institute. Blang Chinese. NCI Thesaurus. Code C158193.

A Chinese person from the Blang ethnic group. 